\title{
Development of on-line FTIR spectroscopy for siloxane detection in biogas to enhance carbon contactor
} management

\author{
C.A. Hepburn ${ }^{\mathrm{a}}$, P. Vale $^{\mathrm{b}}$, A.S. Brown ${ }^{\mathrm{c}}$, N.J. Simms ${ }^{\mathrm{d}}$ and E.J. McAdam ${ }^{\mathrm{a}}$ \\ ${ }^{a}$ Cranfield Water Science Institute, Cranfield University, Bedfordshire, MK43 0AL, UK \\ ${ }^{\mathrm{b}}$ Severn Trent Water Limited, Coventry, CV1 2LZ, UK \\ ${ }^{\mathrm{c}}$ National Physical Laboratory, Teddington, Middlesex, TW11 0LW, UK \\ ${ }^{\mathrm{d}}$ Centre for Power Engineering, Cranfield University, Bedfordshire, MK43 0AL, UK \\ *Corresponding author: Email e.mcadam@cranfield.ac.uk. Telephone 01234754546.
}

\begin{abstract}
Activated carbon filters are used to limit engine damage by siloxanes when biogas is utilised to provide electricity. However, carbon filter siloxane removal performance is poorly understood as until recently, it had not been possible to measure siloxanes online. In this study, on-line Fourier Transform Infrared (FTIR) spectroscopy was developed to measure siloxane concentration in real biogas both upstream $(86.1-157.5$ $\left.\mathrm{mg} \mathrm{m}^{-3}\right)$ and downstream $\left(2.2-4.3 \mathrm{mg} \mathrm{m}^{-3}\right)$ of activated carbon filters. The FTIR provided reasonable precision upstream of the carbon vessel with a root mean square error of $10 \%$ using partial least squares analysis. However, positive interference from volatile organic carbons was observed in downstream gas measurements limiting precision at the outlet to an RMSE of $1.5 \mathrm{mg} \mathrm{m}^{-3}$ (47.8\%). Importantly, a limit of detection of $3.2 \mathrm{mg} \mathrm{m}^{-3}$ was identified which is below the recommended siloxane limit and evidences the applicability of on-line FTIR for this application.
\end{abstract}

\section{1}

Published by Elsevier. This is the Author Accepted Manuscript issued with: Creative Commons Attribution Non-Commercial No Derivatives License (CC:BY:NC:ND 3.0). The final published version (version of record) is available online at DOI:DOI:10.1016/j.talanta.2015.03.063 Please refer to any applicable publisher terms of use. 
Keywords: Adsorption; Biogas; CHP; Landfill; Interference; VOCs 


\section{$1 \quad$ Introduction}

Water utilities have considerable combined heat and power (CHP) engine capacity installed for electrical production. To illustrate, in 2013 UK Water Utilities generated $761 \mathrm{GWh}$ from biogas arising from the anaerobic digestion of sewage sludge (DECC, 2013). To ensure this biogas is utilised economically, volatile methyl siloxanes (VMSs) must be removed as the VMS compounds can cause significant CHP engine damage following their oxidation during combustion which transforms the VMS compounds into silicon dioxide (Arnold, 2009). Some of this silicon dioxide is deposited in the engine as microcrystalline silica, where it abrades the inner surfaces of the combustion chamber (Schweigkofler and Niessner, 2001), clogs valves (Accettola et al., 2008) and reduces engine efficiency (Ohannessian et al., 2008). Damage caused by siloxanes is estimated to cost around $£ 0.015 \mathrm{kWh}^{-1}$ (Lemar, 2005), or $16 \%$ of the current UK feed-in tariff for electricity from CHP engines (£0.094 $\mathrm{kWh}^{-1}$, Read and Hofmann, 2011).

Current best practice for siloxane removal from biogas is pre-treatment using activated carbon (AC) filters (Ajhar et al., 2010a). Whilst many AC filters have been installed at sewage treatment works, there remains relatively little data relating to the effectiveness of these systems. This can, in part, be attributed to the difficulties in measuring siloxanes as until recently the most common methods involved discrete sampling using gas bags (Ajhar et al., 2010b) or canisters (Schweigkofler and Niessner, 1999), followed by analysis using gas chromatography-mass spectrometry (GC-MS) at an external laboratory. Not only is this expensive, at up to $£ 100$ per sample, but the data density provided is insufficient to fully characterise either the siloxane profile of the biogas or the performance of the AC filters. To illustrate, due to cost and logistical constraints, it is rare for biogas sampling to be carried out downstream of the carbon 
filters more than once per day. However, siloxane breakthrough from carbon filters has been noted to increase the carbon filter outlet siloxane concentration from the leakage concentration $\left(\approx 7 \mathrm{mg} \mathrm{m}^{-3}\right)$ to equal the inlet concentration $\left(\approx 100 \mathrm{mg} \mathrm{m}^{-3}\right)$ in less than four hours (Hepburn et al., 2015). This steep breakthrough curve is characteristic of gas adsorption processes (Wakao and Funazkri, 1978; Cooney, 1999) and emphasises the need to provide more frequent analytical measurement of siloxanes to ensure that the carbon vessels are appropriately managed to maintain a reliable barrier to siloxane penetration into the CHP engine.

Arnold and Kajolinna (2010) and Bramston-Cook and Bramston-Cook (2012) were amongst the first to develop online siloxane detection to establish typical siloxane concentrations in real biogas. The authors used portable gas chromatography (GC) to characterise siloxane concentrations in untreated biogas at both sewage treatment works and landfill sites. Both groups demonstrated the ability of field GC to measure siloxanes in the complex biogas matrix, although Arnold and Kajolinna (2010) did note difficulty interpreting chromatograms due to the presence of other interfering volatile organic carbon species (VOCs). Whilst the authors' proved portable GC useful for both detection and speciation of siloxanes in real biogas, field GC techniques require regular calibration and specialist maintenance, which are practically constraining for more permanent installations to be operated by non-specialist staff. Oshita et al. (2010) applied Fourier Transform Infrared (FTIR) spectroscopy to determine the dynamic variation in siloxane concentration in biogas produced at a sewage treatment plant in Japan. The advantage of FTIR is that it requires only initial calibration, an annual maintenance cycle, and takes only around eight minutes to acquire background and sample spectrums (Bendini et al., 2007), making FTIR a more practicable technology 
for long term use by non-specialist operators, to monitor AC filter performance. Similar to Arnold and Kajolinna (2010), Oshita et al. (2010) found that in real biogas, the online results were higher than the results from laboratory GC-MS, and whilst VOCs were not measured directly, the authors also proposed that this was due to positive interference caused from VOCs. Nevertheless, Oshita et al. (2010) achieved a close correlation between on-line FTIR and laboratory GC-MS data in both synthetic and real biogas, despite the size of the siloxane peaks, which are approximately $1 / 50^{\text {th }}$ of the height of the peaks caused by the bulk gases (see supplementary data, Figure S1).

To date, each of the published studies using on-line detection for siloxane measurement have focused on quantitation of siloxanes in raw biogas, i.e. before biogas treatment by activated carbon. However, it is the siloxane data collected downstream of the carbon filter that is used to manage the process. The aim of this study is therefore to investigate the applicability of on-line FTIR for enhancement of carbon vessel management to further improve economic utilisation of biogas as a fuel. The objectives of this study are: (i) to calibrate an industrial FTIR spectrometer for siloxanes using synthetic reference gases; (ii) to investigate the applicability of FTIR for use on real biogas both upstream and downstream of an activated carbon filter; (iii) use laboratory based GC-MS methods to discriminate and diagnose field data; (iv) to refine calibration for use in real biogases and validate calibration using a certified primary reference gas mixture from a National Measurement Institute; and (iv) to develop some of the first seen breakthrough curves from full scale carbon vessels for siloxane removal to illustrate the utility of on-line siloxane measurement for enhancing carbon filter management. 


\section{$2 \quad$ Materials and Methods}

\subsection{Instrument and set up}

The Fourier Transform Infrared spectrometer was an Antaris Industrial Gas System (Thermo Fisher Scientific Inc, Waltham, MA). The gas cell had a $2 \mathrm{~m}$ path length and was operated at $80^{\circ} \mathrm{C}$ to minimise the probability of condensation within the cell. The mirrors within the gas cell were coated with gold to limit deposition of carbon fines introduced in the biogas. Background spectra (found by scanning with the gas cell evacuated) were subtracted from the sample spectrum and the reported value was ascertained from the average value of the scans, with cyclic siloxanes discriminated at $817-798 \mathrm{~cm}^{-1}$. This region corresponds to the infrared (IR) absorbance caused by the $\mathrm{Si}-\left(\mathrm{CH}_{3}\right)_{2}$ group (Table 1) and was subject to integration to identify corresponding concentration.

\subsection{Calibration and verification}

Reference gas was generated by spiking a carrier gas (carbon dioxide or nitrogen) with D5 using the apparatus described in Supplementary Information. The test rig was connected directly to the inlet of the spectrometer gas cell, so that gas constantly flowed through the gas cell. To validate the FTIR results, gas samples (as biogas or synthetics gases produced in $\mathrm{CO}_{2}$ or $\mathrm{N}_{2}$ ) were collected downstream of the FTIR gas cell into Type 232 SKC gas bags (Tedlar body and polypropylene fitting) which Ajhar et al. (2010b) demonstrated to provide high and stable recovery of siloxanes from gas samples. Collected gas samples were subject to GC-MS analysis using an ISO17025 accredited method for siloxane determination. The method requires $100-250 \mathrm{ml}$ of gas for transfer onto a Tenax adsorption tube at a flow rate of $30-50 \mathrm{ml} \mathrm{min}^{-1}$. A stock standard 
containing eight siloxane species and toluene is used to prepare at least four calibration tubes. The samples, calibration standards, QC standards, drift checks and blanks were all analysed using a Markes Unity ATD system connected to an Agilent 5890/5973 GCMS system (CERAM, 2012). The limit of detection was equivalent to $1 \mathrm{mg} \mathrm{m}^{-3}$ in the original sample. To verify the final method, the FTIR was challenged with a primary reference gas mixture (PRGM) supplied by the National Physical Laboratory (NPL, Teddington, UK) which had an amount fraction of $6.9 \mu \mathrm{mol} \mathrm{mol}{ }^{-1}$ of D5 in methane (110 $\mathrm{mg} \mathrm{m}^{-3}$ of D5 in methane at standard temperature and pressure). Gas bag samples were also prepared with the PRGM and analysed using GC-MS, which evidenced an error between the measured and expected siloxane concentration of below $3 \%$ which confirmed gas sample stability within the bag samples taken.

To evaluate the FTIR spectrometer on real biogas, the unit was moved to a large sewage treatment works and connected to gas sampling points upstream and downstream of a full-scale activated carbon vessel $\left(6.76 \mathrm{~m}^{3}, 3000 \mathrm{~kg}_{\text {carbon }}\right)$. The sampling lines were purged for two minutes (greater than three line volumes) before FTIR readings were taken. When undertaking measurements, sample gas was drawn through the gas cell by vacuum pump with 20 scans taken over 120 s. Bag samples were also collected for GC-MS analysis from the gas sampling lines upstream and downstream of the activated carbon vessel by disconnecting the sampling line from the inlet of the FTIR spectrometer immediately after taking a FTIR reading. Samples upstream and downstream of the carbon filter were also subject to analysis by GC-MS for a suite of VOCs using a UKAS accredited method. 


\subsection{Data analysis}

To distinguish trueness and precision for the produced FTIR data (using GC-MS data as the benchmark), two statistics have been used: the coefficient of determination $\left(r^{2}\right)$ and the root mean square error (RMSE). The coefficient of determination is a measure of precision (Miller and Miller, 2005) where RMSE is a measure of overall accuracy, combining trueness and precision, and is commonly used for calibrating new FTIR methods (Bendini et al., 2007; Bertran et al., 1999):

$R M S E=\sqrt{\frac{\sum_{i=n}^{i}\left(y_{i, F T I R}-y_{i, G C-M S}\right)^{2}}{n}}$

where $y_{i, F T I R}$ is the FTIR reading for sample $i, y_{i, G C-M S}$ is the GC-MS results for sample $i$ and $n$ is the number of samples. The limit of detection (LOD) was given by:

$L O D=y_{B}+3 s_{B}$

where $y_{B}$ is the blank signal, considered equal to the $y$-intercept of the line of regression, and $s_{B}$ is the standard deviation of the blank signal, considered equal to $s_{y / x}$, the standard deviation of each data point in the y-direction (Miller and Miller, 2005).

\section{$3 \quad$ Results}

\subsection{FTIR calibration using reference gas and real biogas}

Decamethylcyclopentasiloxane (D5) was the dominant siloxane in the sewage sludge digester biogas, both upstream $\left(68.2-131.0 \mathrm{mg} \mathrm{m}^{-3}\right)$ and downstream $\left(2.2-4.3 \mathrm{mg} \mathrm{m}^{-}\right.$

${ }^{3}$ ) of the carbon vessel (Table 2). This correlates with other studies which also found D5 to be the most abundant siloxane in digester gas (Arnold and Kajolinna, 2010; Oshita et al., 2010; Rasi et al., 2010; Bramston-Cook and Bramston-Cook, 2012). Due to the dominance of cyclic siloxanes (85 - 95\% of siloxanes in upstream samples and $100 \%$ in 
downstream samples) this study used D5 to provide calibration of the FTIR instrument for cyclic siloxanes.

To establish responsiveness of the FTIR spectrometer to D5, reference gases were produced in an environmentally relevant concentration range, between $5-85$ $\mathrm{mg}_{\mathrm{D} 5} \mathrm{~m}_{\text {carrier gas }}^{-3}$ (Figure 1). To illustrate FTIR responsiveness within different absorption regions, absorbance peak heights corresponding to the $\mathrm{Si}-\mathrm{O}$ bond and $\mathrm{Si}-\mathrm{CH}_{3}$ bond were evidenced and indicated a strong correlation with the expected D5 concentration in the siloxane reference gas $\left(r^{2}=0.99\right.$ for both correlations, Supplementary Information, Figure S2). To establish a preliminary calibration, the resultant integrated FTIR data at each estimated D5 concentration was ascertained $\left(r^{2}=\right.$ 0.97, Figure 1). For external verification of the calibration, FTIR results were compared to those produced by GC-MS (Figure 2). A strong linear relationship was found, with $r^{2}$ $=0.99$ for D5-spiked nitrogen and $r^{2}=0.98$ for D5-spiked carbon dioxide. In both reference gases the FTIR readings are higher than the GC-MS results, $60-120 \%$ higher for D5 in nitrogen and 30 - 80\% higher for D5 in carbon dioxide.

When the FTIR system was applied for the determination of siloxanes in real biogas, D5 concentrations of $77-109 \mathrm{mg} \mathrm{m}^{-3}$ were recorded upstream of the AC filter. The FTIR data was subsequently compared to siloxane analysis by GC-MS, produced from the same biogas samples for external verification of FTIR accuracy in the complex biogas matrix (Figure 3). Upstream of the carbon filter, the correlation between FTIR and GCMS data was strong $\left(r^{2}=0.86\right.$, Figure $\left.3 a\right)$ although the FTIR data was $0-25 \%$ lower than the GC-MS data. The RMSE was $15.8 \mathrm{mg} \mathrm{m}^{-3}$ or $15.7 \%$. In biogas samples downstream of the carbon vessel, the data range was narrow $\left(6.4-7.9 \mathrm{mg} \mathrm{m}^{-3}\right)$ and the correlation between the two methods was weaker $\left(r^{2}=0.52\right.$, Figure $\left.3 b\right)$. The FTIR data 
was $84-214 \%$ higher than the GC-MS data and the RMSE was $4.5 \mathrm{mg} \mathrm{m}^{-3}$, although the higher relative RMSE (147\%) can be anticipated in downstream samples due to the lower siloxane concentration.

\subsection{Volatile organic carbons in biogas samples}

A wide number of additional volatile organic carbon (VOC) compounds were found in the real biogas at concentrations ranging from $1.5 \mathrm{mg} \mathrm{m}^{-3}$ (cumene) to $54 \mathrm{mg} \mathrm{m}^{-3}$ (decane) (Figure 4). The VOC concentrations were almost all lower downstream of the carbon vessel, ranging from $1.3 \mathrm{mg} \mathrm{m}^{-3}$ (alpha-pinene) to $18.8 \mathrm{mg} \mathrm{m}^{-3}$ (m,p-xylene)

(Figure 4a), indicating that the activated carbon also adsorbs the VOCs in addition to the target siloxanes. However, the molar ratio with respect to D5 of most species was higher downstream of the carbon vessel (Figure 4b). For example, the molar ratio of benzene to D5 upstream of the vessel was 0.69 and downstream of the vessel was 4.02, and for m,p-xylene, the molar ratio of m,p-xylene to D5 upstream and downstream of the carbon vessel were 3.32 and 9.12 respectively which confirms that the carbon filter was removing siloxanes preferentially to VOCs. Importantly, many of the determined VOC species absorb infrared radiation within the target region of the FTIR spectrum for siloxane quantitation (Table 3).

\subsection{Partial Least Squares calibration and verification using primary reference gas}

A new analysis using a Partial Least Squares (PLS) method was developed for the FTIR spectrometer with the collated spectra from real and synthetic biogas to provide an enhancement in resolution over the original method which used a Classical Least Squares (CLS) technique. A new region of the infrared absorbance spectrum was 
included at $1114.65-991.23 \mathrm{~cm}^{-1}$, to utilise the absorbance peak caused by the stretching of the Si-O-C bond (Table 1). The region of the spectrum analysed to detect the $\mathrm{Si}-\mathrm{CH}_{3}$ bond was also expanded from $817.67-798.39 \mathrm{~cm}^{-1}$ to $879.38-798.39 \mathrm{~cm}^{-1}$. Re-evaluation of the original FTIR spectra was undertaken using the new PLS method and improved RMSEs to $9.8 \mathrm{mg} \mathrm{m}^{-3}(9.7 \%)$ and $1.5 \mathrm{mg} \mathrm{m}^{-3}$ (47.8\%) for upstream and downstream data respectively, and the LOD was reduced from $6.9 \mathrm{mg} \mathrm{m}^{-3}$ to $3.2 \mathrm{mg} \mathrm{m}^{-3}$ (Table 4). The primary reference gas mixture $\left(110 \mathrm{mg}_{\mathrm{D} 5} \mathrm{~m}_{\mathrm{CH} 4}^{-3}\right)$ was used to verify the PLS calibration, and recorded a data range between $109.83 \mathrm{mg} \mathrm{m}^{-3}$ to $119.37 \mathrm{mg} \mathrm{m}^{-3}$ (mean $114.2 \mathrm{mg} \mathrm{m}^{-3}$ ), only $3.8 \%$ higher than the expected value, which is within the uncertainty of the measurement (Table 4). For comparison, a concentration range of $83.22 \mathrm{mg} \mathrm{m}^{-3}$ to $91.15 \mathrm{mg} \mathrm{m}^{-3}$ (mean $87.6 \mathrm{mg} \mathrm{m}^{-3}$ ) was recorded for the original CLS method, around $20.4 \%$ lower than the expected value.

\subsection{Application to full scale contactors}

The FTIR spectrometer was used to construct a breakthrough curve for the full-scale carbon vessel at the sewage treatment works (Figure 5). The mass of siloxane passing into the engine can be calculated by integrating under the outlet concentration graph: $0.94 \mathrm{~kg}$ of siloxane was found to have entered the engine before breakthrough (over a period of 18 days, light grey). When breakthrough begins, the cyclic siloxane concentration in the outlet gas rises from $18 \mathrm{mg} \mathrm{m}^{-3}$ to $101 \mathrm{mg} \mathrm{m}^{-3}$ in four hours. A further $0.94 \mathrm{~kg}$ of siloxane entered the engine during the three days after breakthrough (medium grey), which is equivalent to the minimum time typically required for external analysis of a grab sample taken at the point of breakthrough. The potential for siloxaneinduced damage is therefore doubled if breakthrough is not measured using on-line 
analysis. However, at the case study sewage treatment works, on-line analysis was not used to inform when the carbon beds should be changed, and as the point of grab sampling did not correspond to breakthrough, the AC filter was operated for 29 days between carbon changes, during which an estimated total mass of $4.60 \mathrm{~kg}$ of siloxane entered the engine.

\section{Discussion}

This study has shown that FTIR spectroscopy can be applied for the quantitation of siloxanes in biogas both upstream and downstream of activated carbon vessels. In the initial FTIR assessment of biogas using a CLS method, data produced were predominantly within 95\% confidence limits (Figure 3). The FTIR data demonstrated excellent linearity $\left(r^{2} 0.98-0.99\right)$ for reference gases (Figure 2$)$ and strong linearity for the real biogas sampled upstream $\left(r^{2} 0.86\right)$. This is equivalent to the results of Oshita et al. (2010) who achieved $r^{2} 0.98-0.99$ for synthetic biogas and $r^{2} 0.90$ for real biogas using FTIR spectroscopy (which was not pre-treated with carbon) (Table 4). The RSME of $9.7 \%$ determined for upstream biogas data is comparable to the $10 \%$ error estimated by Arnold and Kajolinna (2010) using field GC with a photo-ionisation detector (Table 4).

However, biogas composition, including compositional variation in bulk gases, has an effect on the FTIR spectra. This was demonstrated through comparison of different carrier gases $\left(\mathrm{N}_{2}\right.$ and $\left.\mathrm{CO}_{2}\right)$ in the reference gases (Figure 2) and was further evidenced in the real biogas evaluation (Figure 3) with the original CLS method where FTIR siloxane data was below the expected concentration in biogas based on GC-MS analysis, which indicated a negative bias when in the presence of carbon dioxide and 
other bulk gases. Nitrogen is a homonuclear diatomic molecule and therefore does not absorb infrared radiation (Stuart, 2004). However, when carbon dioxide was used as the carrier gas, the FTIR siloxane concentration readings were lower (Figure 2). Carbon dioxide and methane are known to cause interference during measurement of VOCs with FTIR. For example, Lechner et al. (2001) identified interference by carbon dioxide when measuring benzene in air near a paper mill. The effect of bulk gases depends on the temperature and pressure in the gas cell and on the relative sizes of the target and matrix molecules (Marshik and Perez, 2013), with negative bias being a common response to interference from non-target compounds (Lorberau, 1990; Williams et al., 2014). However, the proportion of bulk gases in biogas are reasonably stable (Rasi et al., 2010), thus the spectral interference imposed by the bulk gas matrix can be accounted for (Marshik and Perez, 2013). This is evidenced by the good correlation between FTIR and GC-MS results in real biogas $(\mathrm{RSME}=15.7 \%$, Figure 3a) which indicates that the interference imposed by bulk gases was consistent and can be compensated for through calibration.

In this study, sixteen other non-target VOC species containing aliphatic $=\mathrm{C}-\mathrm{H}$ bonds and/or aromatic C-H bonds (which absorb infrared radiation in the region 1000$600 \mathrm{~cm}^{-1}$ and $900-690 \mathrm{~cm}^{-1}$ respectively, Table 3) were identified in biogas at the case study site (Figure 4). The ratio of these non-target VOCs relative to the concentration of D5 was higher in biogas samples downstream of the carbon vessel (Figure 4). Interestingly, in the downstream biogas samples, FTIR siloxane data was higher than determined using GC-MS, without changes to bulk gas composition observed, and is counter to that observed upstream. It is therefore postulated that the higher VOC/siloxane molar ratio observed downstream of the carbon filter introduced positive 
interference to siloxane measurement in downstream samples. Whilst VOC analysis was not undertaken in their study, Oshita et al. (2010) also suggested positive interference from VOCs to explain the higher readings produced from on-line FTIR when applied to biogas with a lower siloxane concentration than observed in this study (Table 4). Lechner et al. (2001) also reported positive interference when developing a method to discriminate compounds which absorb in similar spectral regions, finding difficulty differentiating between different alcohols, acetates and methyl-alkanes in air from the production hall of a recycling centre. Such analyses ostensibly require more complex analytical methods to incorporate spectral correction that allows for interference ( $\mathrm{Li}$ et al., 2002). Consequently, the infrared spectra in this study were reanalysed using a PLS method as this is considered to be more effective for complex mixtures (Stuart, 2004). The PLS method also incorporated a new region of the infrared absorbance spectrum: $1114.65-991.23 \mathrm{~cm}^{-1}$ which includes the resonance frequency of the Si-O-C bond stretching. The Si-O bond absorbs infrared radiation strongly (Stuart, 2004; Coates, 2000) resulting in a tall absorbance peak (see Supplementary Information, Figure S1), making siloxane quantitation easier. The systematic error was reduced by more than $50 \%$, enabling a lower limit of detection of $3.2 \mathrm{mg} \mathrm{m}^{-3}$ and the improved accuracy demonstrated with the PRGM (Table 4). Further enhancement of the LOD for field based FTIR could be achieved through increasing data density to refine the PLS method at the lower concentration limit. To illustrate, Marshik and Zemek (2012) achieved a LOD of 300 - 500 ppbv with FTIR through diluting biogas samples to ascertain trace siloxane concentrations sufficient for calibration at the lower concentration range. Importantly, the LOD determined in this study is below the siloxane limit set by CHP engine manufacturers for inlet gas quality of $6 \mathrm{mg} \mathrm{m}^{-3}$ (Deutz), $12 \mathrm{mg} \mathrm{m}^{-3}$ (Jenbacher, 
Caterpillar) and $30 \mathrm{mg} \mathrm{m}^{-3}$ (Waukesha), demonstrating the industrial applicability of online FTIR for AC filter management.

Preliminary cost savings can be evidenced by direct comparison with current bag sampling methods. The cost of a field ready FTIR unit is around $£ 50,000$ (including multi-sampling-point installation) which compares to an annual cost of around $£ 36,500$ for bag sampling (based on one sample per day), providing a payback period of 16 months. However, the total cost benefit for the implementation of FTIR is best described by the improvement in engine protection through better carbon filter management (Table 5). To illustrate, at the case study sewage treatment works, it was observed that whilst the carbon bed was operated for 29 days, carbon bed breakthrough occurs at around two weeks, after which the siloxane concentration exceeds the engine manufacturer's siloxane specification, which triggers carbon replacement (Figure 5). Replacing the carbon every two weeks (i.e. at breakthrough) instead of every four weeks, doubles carbon cost but suggests a reduction in the mass of siloxane which enters the CHP engine by up to $80 \%$ (Figure 5). Using data from site and from Tower and Wetzel (2006) to estimate the lower engine maintenance threshold that can be achieved through the use of FTIR to trigger carbon changes, indicates a net saving of $£ 328,000$ per year for the case study STW (saving of around $£ 0.007 \mathrm{kWh}^{-1}$ ) or a payback period of two months for an FTIR spectrometer (Table 5).

\section{Conclusions}

Excellent linearity was found when on-line FTIR spectroscopy and laboratory GC-MS results from synthetic reference gas were compared and good linearity was found for real biogas samples upstream of the carbon vessel. Positive interference from VOCs 
limited precision in downstream gas samples, but introducing a partial least squares methodology to analyse the infrared spectra led to a limit of detection of $3.2 \mathrm{mg} \mathrm{m}^{-3}$ being achieved, indicating the FTIR analysis is industrially relevant. The improved carbon management that FTIR analysis can facilitate leads an estimated economic return of $£ 0.007 \mathrm{kWh}^{-1}$, or $50 \%$ of the estimated associated cost of siloxane damage.

\section{Acknowledgements}

The authors would like to thank the Engineering and Physical Sciences Research Council (EPSRC) and Severn Trent Water Limited for their financial support and also thank to Thermo Scientific (Madison, WI), in particular J. Roberts, S. Halsey and M. Arrowsmith, for their assistance with the calibration of the FTIR spectrometer.

\section{References}

Accettola, F., Guebitz, G. M., Schoeftner, R., 2008. Siloxane removal from biogas by biofiltration: Biodegradation studies. Clean Technol. Environ. Policy. 10 (2), 211-218.

Ajhar, M., Travesset, M., Yüce, S., Melin, T., 2010a. Siloxane removal from landfill and digester gas - A technology overview. Bioresource Technol. 101 (9), 2913-2923.

Ajhar, M., Wens, B., Stollenwerk, K. H., Spalding, G., Yüce, S., Melin, T., 2010. Suitability of Tedlar® gas sampling bags for siloxane quantification in landfill gas. Talanta. $82(1), 92-98$.

Arnold, M., 2009. Reduction and monitoring of biogas trace compounds. VTT Research notes, 2496 VTT, Espoo. 
Arnold, M., Kajolinna, T., 2010. Development of on-line measurement techniques for siloxanes and other trace compounds in biogas. Waste Manage. 30 (6), 1011-1017.

Bendini, A., Cerretani, L., Di Virgilio, F., Belloni, P., Bonoli-Carbognin, M., Lercker, G., 2007. Preliminary evaluation of the application of the FTIR spectroscopy to control the geographic origin and quality of virgin olive oils. J. Food Quality. 30 (4), 424-437.

Bertran, E., Blanco, M., Coello, J., Iturriaga, H., Maspoch, S., Montoliu, I., 1999.

Determination of olive oil free fatty acid by Fourier transform infrared spectroscopy. J. Am. Oil Chem. Soc. 76 (5), 611-616.

Bramston-Cook, E., Bramston-Cook, R., 2012. Online, direct measurement of volatile siloxanes in anaerobic digester and landfill gases by gas chromatography with mass spectrometric detection, in: Air and Waste Management Association (ed.), Air Quality Measurement Methods and Technology Conference 2012, 24-26 April 2012, Durham, North Carolina, Curran Associates, New York, pp. 438-443.

CERAM, 2012. Analysis of landfill gas and biogas for siloxanes by automated thermal desoprtion-gas chromatography-mass spectrometry. CERAM, Stoke-on-Trent, UK.

Coates, J., 2000. Interpretation of infra-red spectra, a practical approach, in Meyer, R. A. (ed.) Encyclopedia of Analytical Chemistry. Wiley, Chichester, UK, pp. 1081510837.

Cooney, D. O., 1999. Adsorption design for wastewater treatment. CRC Press LLC, Florida.

DECC 2013. Digest of United Kingdom energy statistics chapter six: Renewable sources of energy. DUKES, Department for Energy and Climate Change, London. 
Hepburn, C. A., Martin, B. D., Simms, N., McAdam, E. J., 2015. Characterization of full-scale carbon contactors for siloxane removal from biogas using online Fourier transform infrared spectroscopy. Environ. Technol. 36 (2), 178-187.

Lechner, B., Paar, H., Sturm, P. J., 2001. Measurement of VOCs in vehicle exhaust by extractive FT-IR-spectroscopy, in: Fujisada H., Lurie J.B., Ropertz A., Weber, K., (eds.), Sensors, Systems, and Next-Generation Satellites IV, SPIE, Barcelona, pp. 432.

Lemar, P., 2005. CHP systems for landfills and wastewater treatment plants. Intermountain CHP Centre workshop, 11/08/2005, Salt Lake City, UT.

Li, Y., Wang, J. D., Huang, Z. H., Xu, H. Q., Zhou, X. T., 2002. Monitoring leaking gases by OP-FTIR remote sensing. J. Environ. Sci. Heal. A. 37 (8), 1453-1462.

Lipp, E. D., Smith, A. L., 1991. Infrared, raman, near-infrared and ultraviolet spectroscopy, in: Smith, A. L. (ed.) The analytical chemistry of silicones. Wiley, New York, pp. 245-305.

Lorberau, C., 1990. Investigation of the determination of respirable quartz on filter media using Fourier transform infrared spectrophotometry. Appl. Occup. Environ. Hyg. $5(6), 348-350$.

Marshik, B., Zemek, P. G., 2012. Real-time siloxanes measurements at landfill and digester sites using FTIR, in: Air and Waste Management Association (ed.), Air Quality Measurement methods and Technology Conference, 24-26 April 2012, Durham, North Carolina, Curran Associates, New York, pp. 464-468. 
Marshik, B., Perez, J. E., 2013. Novel improvements in FTIR analysis of specialty gases, in: Geiger, W. M., Raynor, M. W. (eds.), Trace analysis of specialty and electronic gases. Wiley, Hoboken, NJ, pp. 43-70.

Miller, J. N., Miller, J. C., 2005. Statistics and chemometrics for analytical chemistry, fifth ed, Pearson Education, Harlow, UK.

Montanari, T., Finocchio, E., Bozzano, I., Garuti, G., Giordano, A., Pistarino, C., Busca, G., 2010. Purification of landfill biogases from siloxanes by adsorption: A study of silica and $13 \mathrm{X}$ zeolite adsorbents on hexamethylcyclotrisiloxane separation. Chem. Eng. J. 165 (3), 859-863.

Ohannessian, A., Desjardin, V., Chatain, V., Germain, P., 2008. Volatile organic silicon compounds: The most undesirable contaminants in biogases. Water Sci. Technol. 58 (9), 1775-1781.

Oshita, K., Ishihara, Y., Takaoka, M., Takeda, N., Matsumoto, T., Morisawa, S., Kitayama, A., 2010. Behaviour and adsorptive removal of siloxanes in sewage sludge biogas. Water Sci. Technol. 61 (8), 2003-2012.

Rasi, S., Lehtinen, J., Rintala, J., 2010. Determination of organic silicon compounds in biogas from wastewater treatments plants, landfills, and co-digestion plants. Renew. Energ. 35 (12), 2666-2673.

Read, A., Hofmann, F., 2011. Does biogas scrub up? In: Materials Recycling World, 2nd December 2011, EMAP Publishing, London. 
Schweigkofler, M., Niessner, R., 1999. Determination of siloxanes and VOC in landfill gas and sewage gas by canister sampling and GC-MS/AES analysis. Environ. Sci.

Technol. 33 (20), 3680-3685.

Schweigkofler, M., Niessner, R., 2001. Removal of siloxanes in biogases. J. Hazard Mater. 83 (3), 183-196.

Stuart, B., 2004. Infrared spectroscopy: Fundamentals and applications. Wiley, Chichester, England.

Tower, P. M., Wetzel, J. V., 2006. Making power generation make sense by removing siloxanes from digester gas. CWEA Annual Conference, 5-7 April, Sacramento, CA, California Water Environment Association.

Wakao, N., Funazkri, T., 1978. Effect of fluid dispersion coefficients on particle-tofluid mass transfer coefficients in packed beds: Correlation of sherwood numbers. Chem. Eng. Sci. 33 (10), 1375-1384.

Williams, S., Leung, Y., Aleixo, J., Hu,R., 2014. Understanding FTIR formaldehyde measurement and its influence on the RICE NESHAP rule. DCL International, Ontario, Canada. 
Figure 1. Reference gas D5 concentration (in $\mathrm{CO}_{2}$ ) compared to D5 concentration measured by FTIR. The dashed line represents parity $(y=x)$.

Figure 2. FTIR readings compared to GC-MS measurements in synthetic reference gas. $\mathrm{r}^{2}=0.99$ for D5 in $\mathrm{N}_{2}$ and $\mathrm{r}^{2}=0.98$ for D5 in $\mathrm{CO}_{2}$. The dashed line represents parity $(\mathrm{y}=\mathrm{x})$.

Figure 3. FTIR reading for cyclic siloxanes compared to total cyclic siloxanes measured from gas bag samples by GC-MS from biogas (a) upstream of carbon vessel and (b) downstream of carbon vessel. The dashed lines show the $95 \%$ confidence limits.

Figure 4. Volatile organic compounds determined in biogas samples upstream and downstream of a carbon vessel: (a) Concentration; (b) molar ratio to D5. Nonane, decane and carbon disulphide (Marked*), do not contain bonds which are thought to contribute to interference in the FTIR readings.

Figure 5. An example breakthrough curve for a carbon vessel $\left(1.21 \mathrm{~m}^{3}, 450 \mathrm{~kg}_{\text {carbon }}\right)$. The area under the outlet concentration graph can be used to calculate the mass of siloxane entering the engine as follows: light grey $-0.94 \mathrm{~kg}$ over 18 days before breakthrough; mid grey - $0.94 \mathrm{~kg}$ over three days after breakthrough; dark grey - a further $2.72 \mathrm{~kg}$ over eight days before the carbon is changed. 
Table 1. Infrared absorbance peaks for siloxanes.

\begin{tabular}{|c|c|c|c|}
\hline Bond & Molecules & Peak position & Reference \\
\hline \multirow[t]{2}{*}{ Si-O } & \multirow[t]{2}{*}{ All siloxanes } & $1150-1000 \mathrm{~cm}^{-1}$ & $\begin{array}{l}\text { (Oshita et al., } \\
2010)\end{array}$ \\
\hline & & $1035 \mathrm{~cm}^{-1}$ & $\begin{array}{l}\text { (Montanari et al., } \\
\text { 2010) }\end{array}$ \\
\hline \multirow[t]{6}{*}{$\mathrm{Si}-\mathrm{O}-\mathrm{Si}$} & \multirow[t]{6}{*}{ All siloxanes } & near $1050 \mathrm{~cm}^{-1}$ (antisymmetric stretch) & \\
\hline & & $1090 \mathrm{~cm}^{-1}$ (cyclotrisiloxanes) & \\
\hline & & $1020 \mathrm{~cm}^{-1}$ (cyclotetrasiloxanes) & \\
\hline & & $\begin{array}{l}\text { Broad doublet with maxima at } 1020 \text { and } 1090 \mathrm{~cm}^{-1} \text { for more than } \\
\text { twenty coupled siloxane units }\end{array}$ & $\begin{array}{l}\text { (Lipp and Smith, } \\
\text { 1991) }\end{array}$ \\
\hline & & $1095-1075 \mathrm{~cm}^{-1}$ and $1055-1020 \mathrm{~cm}^{-1}$ & (Coates, 2000) \\
\hline & & $1300-1000 \mathrm{~cm}^{-1}$ (asymmetric stretching) & (Stuart, 2004) \\
\hline \multirow[t]{2}{*}{ Si-O-C } & \multirow{2}{*}{$\begin{array}{l}\text { All volatile methyl } \\
\text { siloxanes }\end{array}$} & $1110-1080 \mathrm{~cm}^{-1}$ & (Coates, 2000) \\
\hline & & $1110-1050 \mathrm{~cm}^{-1}$ (stretching) & (Stuart, 2004) \\
\hline \multirow[t]{5}{*}{$\mathrm{Si}-\mathrm{CH}_{3}$} & \multirow[t]{5}{*}{ Linear siloxanes } & $850-770 \mathrm{~cm}^{-1}$ & (Oshita et al., \\
\hline & & $818 \mathrm{~cm}^{-1}$ & 2010) \\
\hline & & Near $775 \mathrm{~cm}^{-1}$ & $\begin{array}{l}\text { (Montanari et al., } \\
\text { 2010) }\end{array}$ \\
\hline & & $1280-1250 \mathrm{~cm}^{-1}$ (symmetric bending) & $\begin{array}{l}\text { (Lipp and Smith, } \\
\text { 1991) }\end{array}$ \\
\hline & & & (Stuart, 2004) \\
\hline $\begin{array}{l}\mathrm{Si}- \\
\left(\mathrm{CH}_{3}\right)_{2}\end{array}$ & Cyclic siloxanes & Near $805 \mathrm{~cm}^{-1}$ & $\begin{array}{l}\text { (Lipp and Smith, } \\
\text { 1991) }\end{array}$ \\
\hline $\begin{array}{l}\mathrm{Si}- \\
\left(\mathrm{CH}_{3}\right)_{3}\end{array}$ & Linear siloxanes & 760 and $845 \mathrm{~cm}^{-1}$ & $\begin{array}{l}\text { (Lipp and Smith, } \\
\text { 1991) }\end{array}$ \\
\hline \multirow[t]{2}{*}{$\mathrm{CH}_{3}$} & Siloxanes & \multirow[t]{2}{*}{$1262 \pm 5 \mathrm{~cm}^{-1}$ and around $800-900 \mathrm{~cm}^{-1}$} & \multirow{2}{*}{$\begin{array}{l}\text { (Lipp and Smith, } \\
\text { 1991) }\end{array}$} \\
\hline & $\begin{array}{l}\text { Many other organic } \\
\text { compounds }\end{array}$ & & \\
\hline
\end{tabular}

2 
Table 2. Speciated siloxanes in sewage treatment works biogas measured by GC-MS $(n=9)$.

1

\begin{tabular}{|c|c|c|c|c|c|c|}
\hline \multirow[t]{2}{*}{ Siloxane species } & \multicolumn{3}{|c|}{$\begin{array}{l}\text { Upstream concentration } \\
\left(\mathrm{mg} \mathrm{m}^{-3}\right)^{\star}\end{array}$} & \multicolumn{3}{|c|}{$\begin{array}{l}\text { Downstream concentration } \\
\left(\mathrm{mg} \mathrm{m}^{-3}\right)^{\star}\end{array}$} \\
\hline & Mean & St. dev. & Range & Mean & St. dev. & Range \\
\hline L2 & 10.0 & 3.2 & $5.3-15.2$ & $<1.0$ & - & - \\
\hline L3 & 1.3 & 0.14 & $1.0-1.5$ & $<1.0$ & - & - \\
\hline L4 & $<1.0$ & - & - & $<1.0$ & - & - \\
\hline D3 & $<1.0$ & - & - & $<1.0$ & - & - \\
\hline D4 & 13.4 & 1.5 & $10.7-16.0$ & $<1.0$ & - & - \\
\hline D5 & 87.7 & 21.0 & $68.2-131.0$ & 3.1 & 0.62 & $2.2-4.3$ \\
\hline
\end{tabular}

*Method detection limit is $1 \mathrm{mg} \mathrm{m}^{-3}$. L - represents a linear siloxane compound (L2-L4): L2 - Hexamethyldisiloxane, L3 Octamethyltrisiloxane, L4 - Decamethyltetrasiloxane. D - represents a cyclic siloxane compound (D3-D5): D3 Hexamethylcyclotrisiloxane, D4 - Octamethylcyclotetrasiloxane, D5 - Decamethylcyclopentasiloxane. 
Table 3. VOC species present in biogas samples and associated infrared absorbance peaks

(Stuart, 2004). The italicised peaks may cause positive interference.

\begin{tabular}{|c|c|c|c|}
\hline Species & Concentration $\left(\mathrm{mg} \mathrm{m}^{-3}\right)$ & Bonds $^{a}$ & Peaks \\
\hline \multicolumn{4}{|l|}{ Alkanes } \\
\hline Nonane & 6 & \multirow[t]{2}{*}{$-\mathrm{CH}_{2-}$} & \multirow[t]{2}{*}{$2930 ; 2850 ; 1465 ; 1305 ; 1300 ; 720$} \\
\hline Decane & 9 & & \\
\hline \multicolumn{4}{|l|}{ Alkenes } \\
\hline \multirow[t]{2}{*}{ 1-butene } & \multirow[t]{2}{*}{3.4} & $=\mathrm{C}-\mathrm{H}$ & $3100-3000 ; 1400 ; 1000-600$ \\
\hline & & $\mathrm{C}=\mathrm{C}$ & $1680-1600$ \\
\hline \multicolumn{4}{|l|}{ Aromatic hydrocarbons } \\
\hline Benzene & 3.6 & $\mathrm{C}-\mathrm{H}$ & $3100-3000 ; 1275-1000 ; 900-690$ \\
\hline Toluene & 25.3 & $\mathrm{C}=\mathrm{C}$ & $1650-1430$ \\
\hline Ethyl benzene & 15.1 & \multirow{13}{*}{$\begin{array}{l}\text { Substituted aromatic } \\
\text { compounds will also } \\
\text { have peaks similar to } \\
\text { the aliphatic } \\
\text { compounds above }\end{array}$} & \\
\hline m,p-xylene & 32.9 & & \\
\hline o-xylene & 11. & & \\
\hline o-ethyltoluene & 16.2 & & \\
\hline m-ethyltoluene & 47.7 & & \\
\hline p-ethyltoluene & 21.0 & & \\
\hline 1,2,3-trimethylbenzene & 5.7 & & \\
\hline 1,2,4-trimethylbenzene & 44.5 & & \\
\hline 1,3,5-trimethylbenzene & 22.2 & & \\
\hline Cumene & 10.9 & & \\
\hline d-limonene & 8.8 & & \\
\hline Alpha-pinene & 9.3 & & \\
\hline Beta-pinene & 3.1 & & \\
\hline \multicolumn{4}{|l|}{ Sulphur compounds } \\
\hline Carbon disulphide & 2.2 & C-S & $700-600$ \\
\hline
\end{tabular}

\footnotetext{
${ }^{a}$ Bonds shown are representative of chemical groups
} 
Table 4. Comparison of on-line analytical procedures for siloxane detection from the literature with the current study.

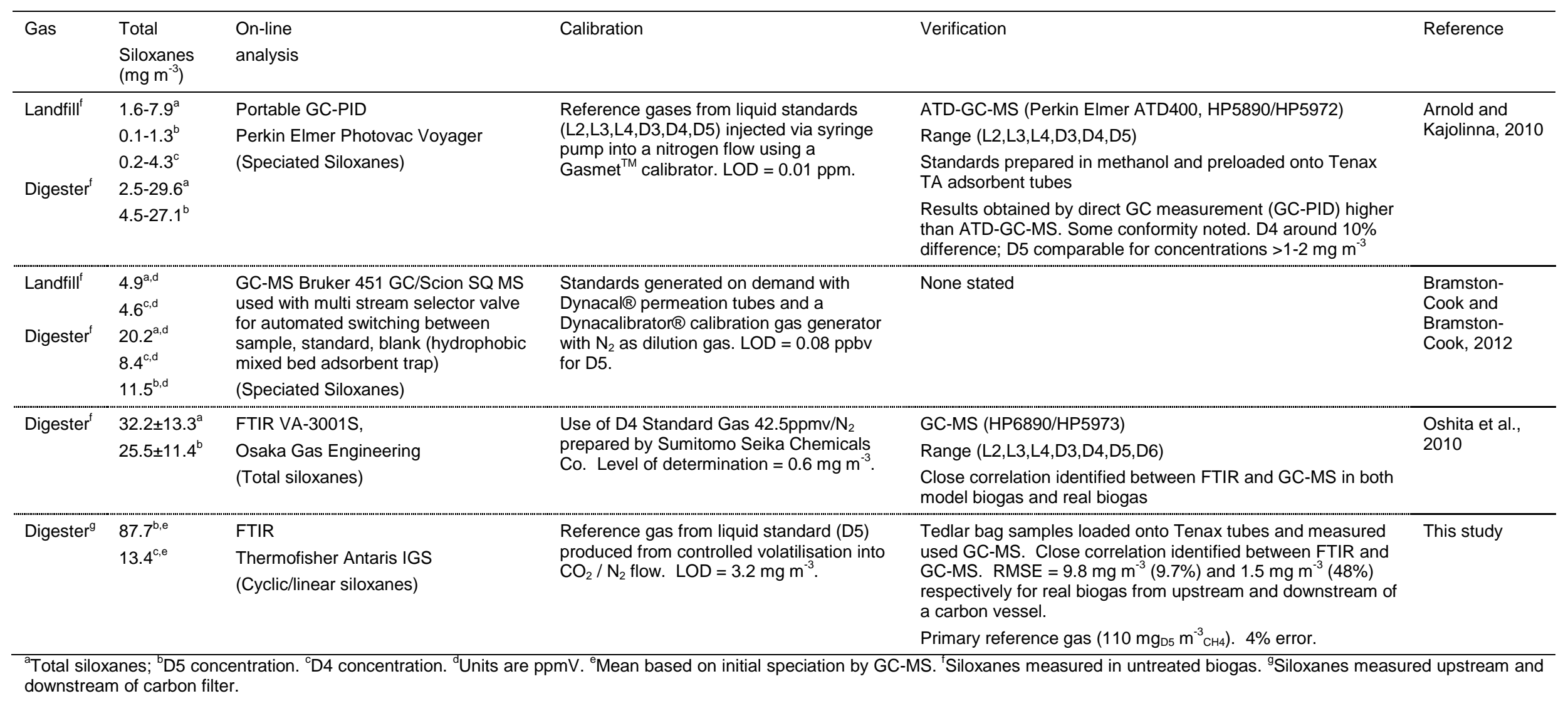


Table 5. Costs of siloxane monitoring, carbon replacement and CHP engine maintenance.

\begin{tabular}{|c|c|c|c|c|c|c|c|}
\hline Scenario & Cost & \multicolumn{2}{|c|}{ No gas treatment } & \multicolumn{2}{|c|}{$\begin{array}{l}\text { Carbon beds changed every four } \\
\text { weeks }\end{array}$} & \multicolumn{2}{|c|}{$\begin{array}{l}\text { Carbon beds changed after breakthrough using } \\
\text { FTIR }\end{array}$} \\
\hline \multicolumn{8}{|l|}{ Siloxane monitoring ${ }^{\mathrm{a}}$} \\
\hline Bag sampling & $£ 100$ & Daily & $£ 36,500$ & Daily & $£ 36,500$ & - & - \\
\hline FTIR service & $£ 1,500$ & - & - & - & - & Annual & $£ 1,500$ \\
\hline \multicolumn{8}{|l|}{ Siloxane removal system ${ }^{\mathrm{a}}$} \\
\hline \multicolumn{8}{|l|}{ Engine maintenance $^{\mathrm{b}}$} \\
\hline Service & $£ 225,000$ & 5000 hours & $£ 390,000$ & 9000 hours & $£ 220,000$ & 20000 hours & $£ 100,000$ \\
\hline Decoke & $£ 50,000$ & nd & $n d^{c}$ & 3000 hours & $£ 150,000$ & 9000 hours & $£ 50,000$ \\
\hline Oil change & $£ 7,500$ & 250 hours & $£ 260,000$ & 500 hours & $£ 130,000$ & 1500 hours & $£ 44,000$ \\
\hline Spark plugs & - & 500 hours & $£ 15,000$ & 1200 hours & $£ 6,000$ & 1500 hours & $\{5,000$ \\
\hline \multicolumn{8}{|l|}{ Engine operation ${ }^{b}$} \\
\hline $\begin{array}{l}\text { Annual saving (compared to bag } \\
\text { sampling) }\end{array}$ & & & - & & - & & $£ 328,000$ \\
\hline Payback period for FTIR spectrometer & $£ 50,000$ & & - & & - & & 2 months \\
\hline
\end{tabular}




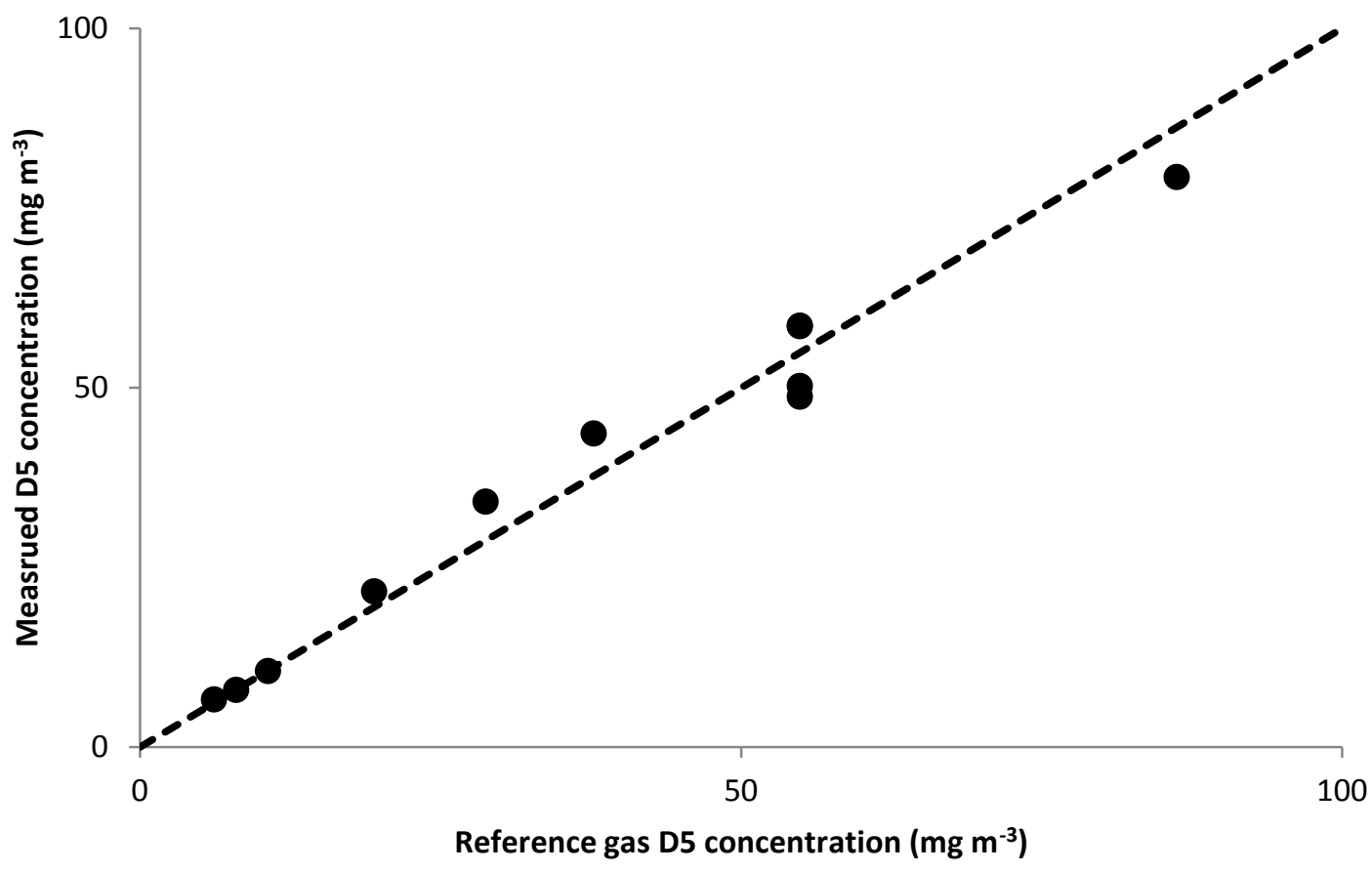

Figure 1. Reference gas D5 concentration (in $\mathrm{CO}_{2}$ ) compared to D5 concentration measured by FTIR. The dashed line represents parity $(y=x)$.

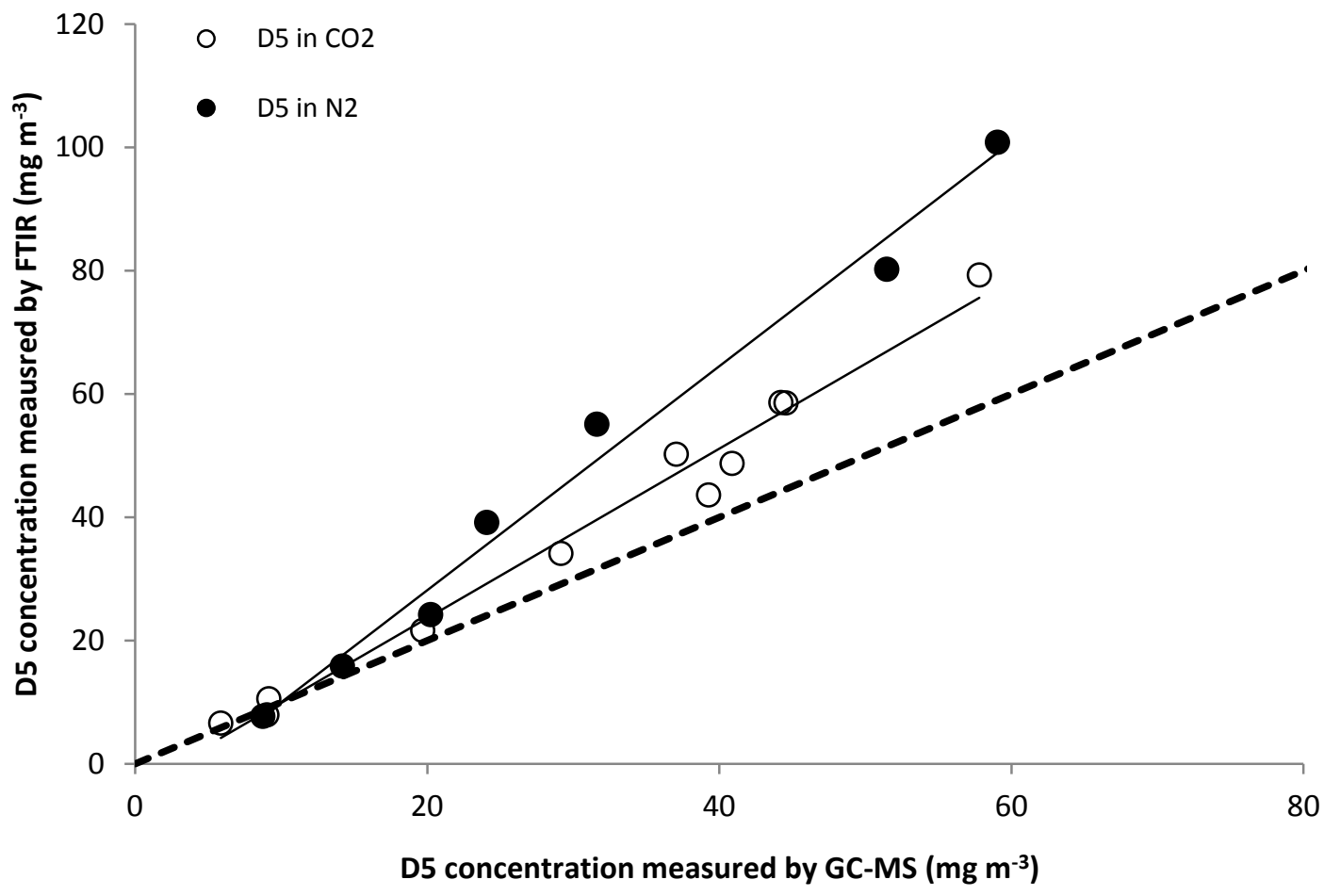

Figure 2. FTIR readings compared to GC-MS measurements in synthetic reference gas. $r^{2}=0.99$ for $\mathrm{D} 5$ in $\mathrm{N}_{2}$ and $\mathrm{r}^{2}=0.98$ for $\mathrm{D} 5$ in $\mathrm{CO}_{2}$. The dashed line represents parity $(\mathrm{y}=\mathrm{x})$. 
(a)
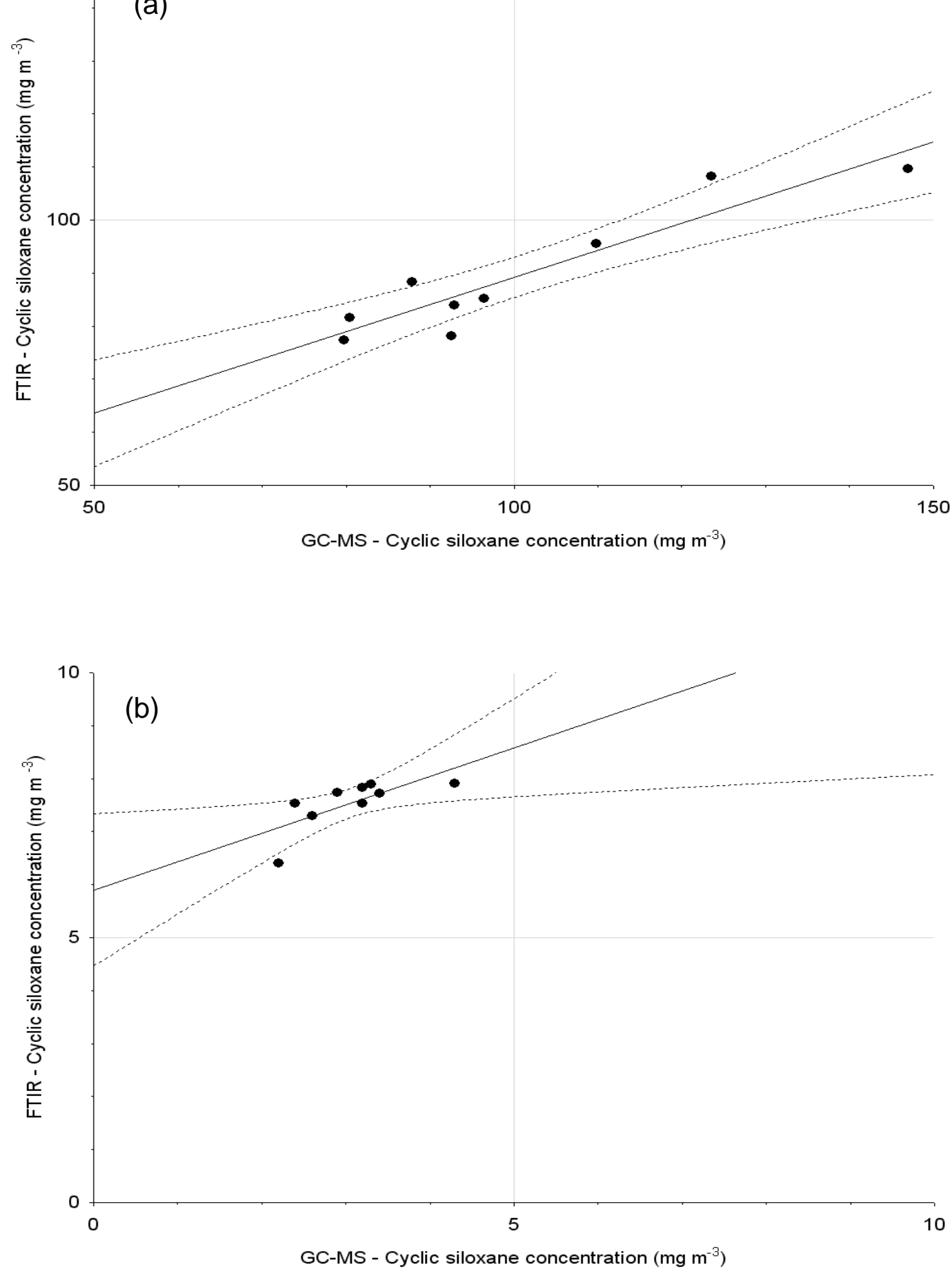

Figure 3. FTIR reading for cyclic siloxanes compared to total cyclic siloxanes measured from gas bag samples by GC-MS from biogas (a) upstream of carbon vessel and (b) downstream of carbon vessel. The dashed lines show the $95 \%$ confidence limits. 

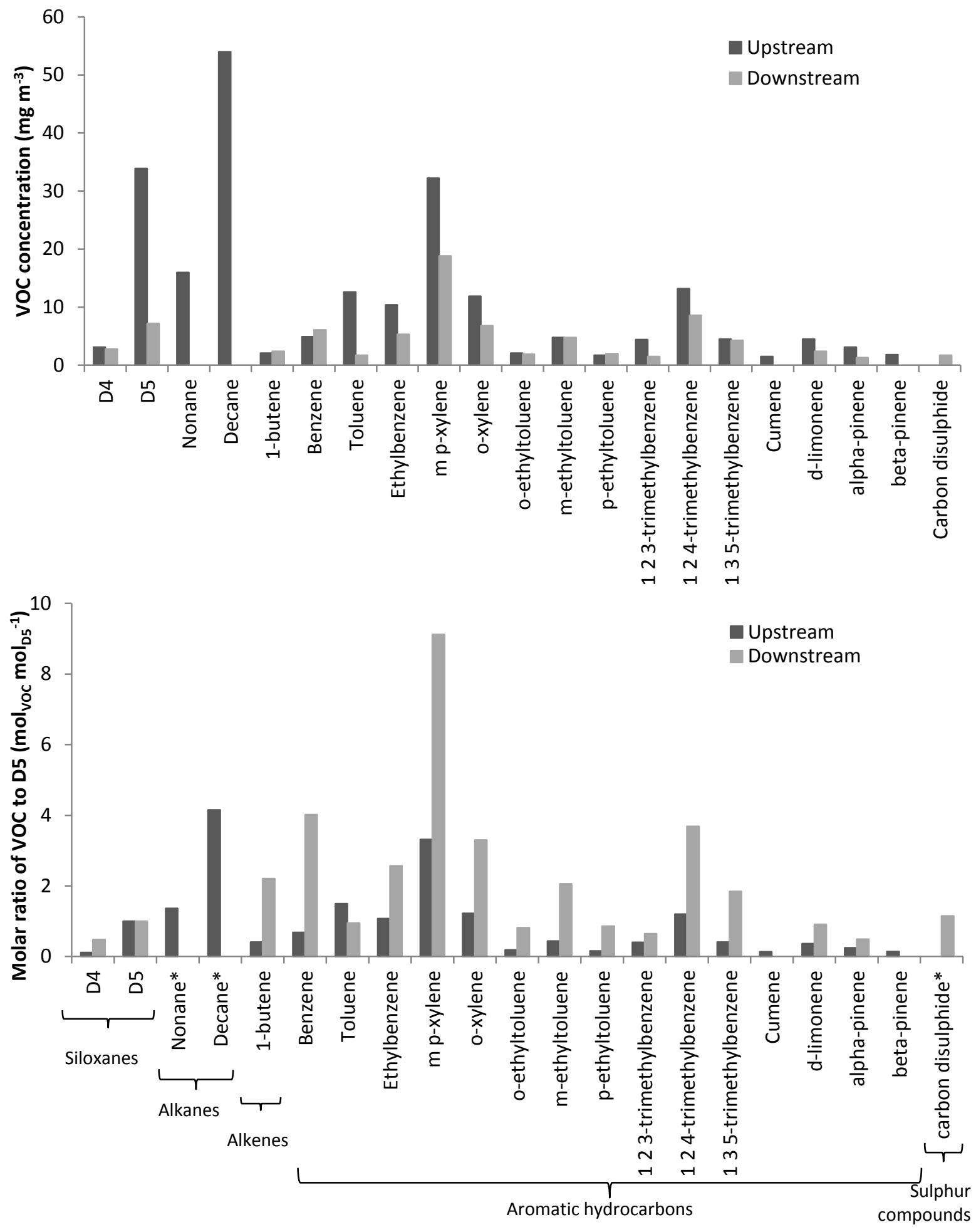

Figure 4. Volatile organic compounds determined in biogas samples upstream and downstream of a carbon vessel: (a) Concentration; (b) molar ratio to D5. Nonane, decane and carbon disulphide (Marked*), do not contain bonds which are thought to contribute to interference in the FTIR readings. 


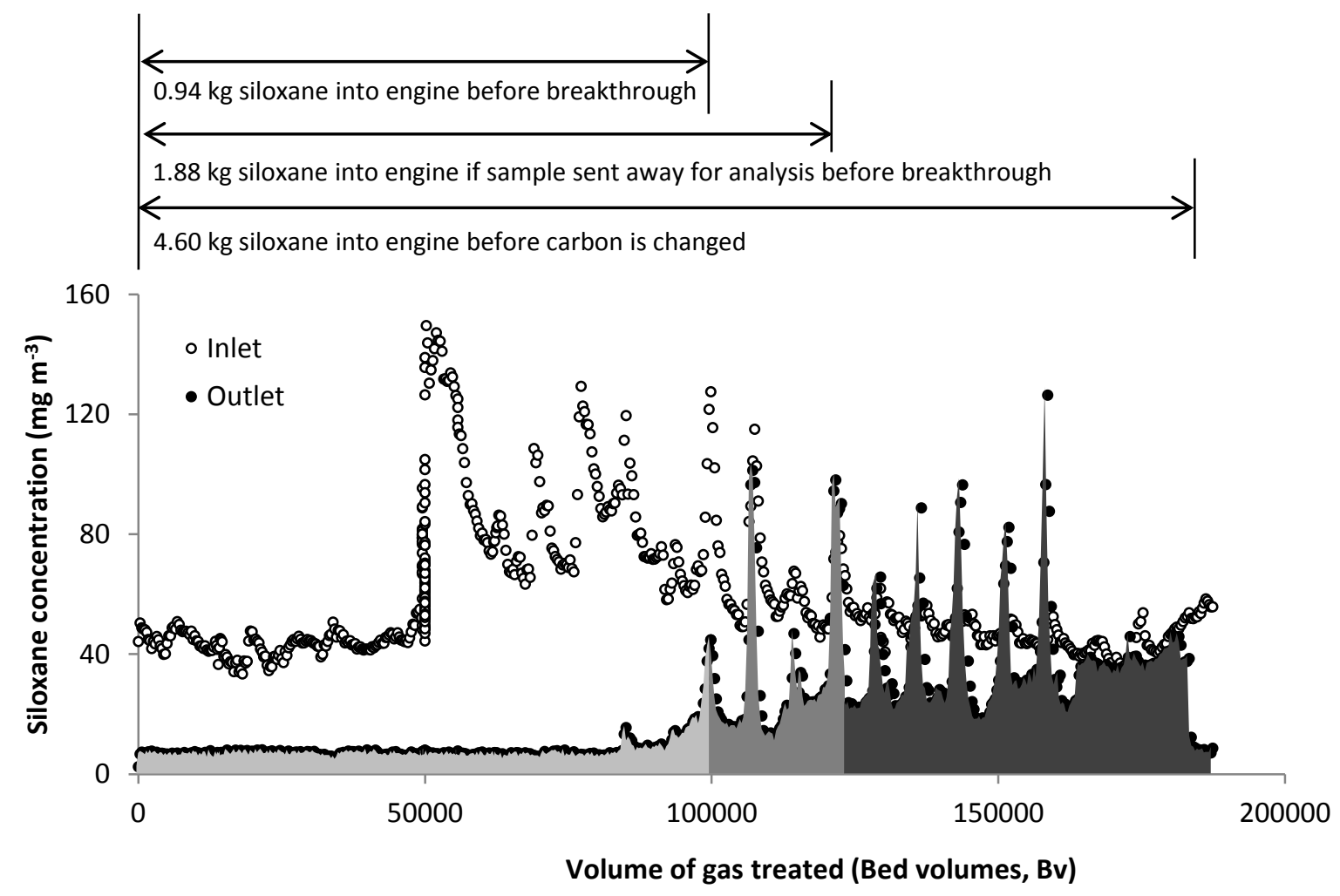

Figure 5. An example breakthrough curve for a carbon vessel $\left(1.21 \mathrm{~m}^{3}, 450 \mathrm{~kg}_{\text {carbon }}\right)$. The area under the outlet concentration graph can be used to calculate the mass of siloxane entering the engine as follows: light grey - $0.94 \mathrm{~kg}$ over 18 days before breakthrough; mid grey - $0.94 \mathrm{~kg}$ over three days after breakthrough; dark grey - a further $2.72 \mathrm{~kg}$ over eight days before the carbon is changed. 